\title{
Pengaruh Terpaan Media Online Terhadap Brand Image Kini
}

\section{Capsule}

\author{
Dionisius Kevin, Wulan Purnama Sari \\ dionisiuskev@gmail.com,wulanp@fikom.untar.ac.id \\ Fakultas Ilmu Komunikasi Universitas Tarumanagara
}

\begin{abstract}
Kini Capsule is a minimalist capsule hotel located in Jakarta. This research aims to discover how big media exposure impacts brand image by using Kini Capsule as its research object. Kini Capsule being picked as a research object for its unique hotel concept, and their marketing strategy that requires only online media. This research is tested quantitatively, using the survey method. The population used in this research are people who had been staying in Kini Capsule with the sample of 100 respondents. The result of this research shows that media exposure had an impact (7,9\%) and significant to the brand image of Kini Capsule and the other 92,1\% are factors that is not being researched on this research. The most impactful dimension on this research belongs to frequency (media exposure) and uniqueness (brand image). As frequency shows how often people expose themselves to a certain information, which means a higher frequency for them to obtain information regarding Kini Capsule. Uniqueness shows differentiation in between Kini Capsule and other hostelry. In this research, uniqueness is being shown through Kini Capsule's pod shape and its architectural Indonesian design. For these reasons are the main reason for people are getting attracted to visit Kini Capsule.
\end{abstract}

Keyword: Media Exposure, Brand Image, Hotel

\begin{abstract}
Abstrak
Kini Capsule adalah sebuah hotel minimalis dengan bentuk kapsul yang berlokasi di Jakarta. Penelitian ini bertujuan untuk mengetahui seberapa besar pengaruh terpaan media online terhadap brand image dengan menggunakan Kini Capsule sebagai objek penelitian. Peneliti memilih Kini Capsule sebagai objek penelitian karena merupakan hotel yang memiliki konsep unik serta menggunakan strategi pemasaran yang memanfaatkan media online. Penelitian ini dilakukan dengan pendekatan kuantitatif dengan metode kuesioner. Populasi Ddalam penelitian ini adalah konsumen yang pernah menginap di Kini Capsule dengan sampel penelitian sebanyak 100 responden. Hasil kesimpulan penelitian menunjukkan bahwa terpaan media memiliki pengaruh sebesar 7,9\% dan signifikan terhadap brand image Kini Capsule, sementara $92,1 \%$ disebabkan oleh faktor lain yang tidak diteliti dalam penelitian ini. Di dalam penelitian ini, terdapat dua dimensi yang paling berpengaruh yakni dimensi frekuensi (terpaan media) dan dimensi keunikan (brand image). Pada dimensi frekuensi dijelaskan mengenai seberapa sering khalayak menerpa dirinya ke dalam informasi, yakni dalam penelitian ini berkaitan dengan semakin tingginya frekuensi seseorang untuk memperoleh informasi mengenai Kini Capsule. Keunikan menjelaskan mengenai perbedaan di antara Kini Capsule dengan penginapan yang lain. Di dalam penelitian ini, keunikan ditunjukan melalui bentuk kapsul Kini Capsule dan desain arsitekturnya yang bertemakan Indonesia. Hal tersebut menjadi faktor utama yang menjadi daya tarik masyarakat untuk datang dan mengunjungi Kini Capsule.
\end{abstract}

Kata kunci: Terpaan Media, Brand image, Hotel. 


\section{Pendahuluan}

Media kerap digunakan sebagai metode untuk mempermudah penyebaran pesan ke banyak khalayak pada era modern ini. Hal ini disebabkan oleh empat karakteristik utama yang dimiliki oleh media, yakni pesan dapat disampaikan tanpa terbatas oleh jarak, pesan disampaikan menggunakan alat, pesan dapat disampaikan dengan cepat pada skala yang besar serta pesan disampaikan secara berbayar (Ardianto, 2014).

Terpaan media mencari data khalayak seputar penggunaan media. Adapun tiga dimensi sebagai indikator terpaan media yaitu frekuensi, durasi dan atensi. Frekuensi pada terpaan media mengumpulkan data dan melihat seberapa sering individu atau kelompok menggunakan media dalam rentang waktu satu minggu atau satu bulan. Lamanya penggunaan media diukur berdasarkan durasi mengikuti media (berapa menit atau jam). Atensi mengukur tingkat perhatian yang diberikan oleh konsumen kepada konten atau informasi yang disajikan, hal ini diukur kembali melalui seberapa paham konsumen terhadap informasi yang disampaikan oleh media.

Khalayak yang menerima informasi dari media terkait sebuah merek kemudian membentuk persepsi terhadap pesan tersebut. Persepsi terhadap pesan ini disebut dengan brand image.

Menurut Kotler \& Keller (2009), brand image adalah persepsi konsumen dan preferensi terhadap merek, sebagaimana yang direfleksikan oleh berbagai macam asosiasi merek yang ada dalam ingatan konsumen. Brand image juga terbagi ke dalam tiga dimensi yaitu, Strength, Favorability dan Uniqueness. Strength berkaitan dengan apakah sebuah merek cukup kuat untuk membentuk citra merek pada benak konsumen. Favorability berkaitan dengan apakah merek dapat menjawab janji-janji pemasaran dan digemari oleh konsumen. Uniqueness berkaitan dengan diferensiasi antara merek yang satu dengan yang lain. Penilaian terhadap citra merek dapat diperoleh dengan memperkenalkan merek kepada konsumen, salah satunya melalui pemasaran menggunakan media. Tidak hanya media konvensional seperti televisi, namun juga media online yang terbentuk akibat perkembangan teknologi dan komunikasi. Kemajuan teknologi mendorong bisnis untuk semakin berkembang karena tersedianya teknologi pendukung. Pemanfaatan teknologi yang saat ini sedang trend salah satunya adalah media online. Internet telah menjadi salah satu hal penting dalam bisnis terutama dalam pemasaran atau marketing.

Strategi pemasaran melalui media online seperti website maupun media sosial telah menjadi cara baru untuk mencapai target dan mendapatkan pelanggan yang tepat. Brand image yang dipasarkan melalui media akan dinilai dalam benak masingmasing konsumen sesuai dengan informasi yang diperoleh. Bisnis perhotelan di Indonesia juga telah memasuki era baru. Kondisi ini didorong oleh adanya perubahan di berbagai bidang, meliputi perkembangan teknologi komunikasi, munculnya generasi millenials sebagai penggerak pertumbuhan ekonomi, kebutuhan pola pikir, pola kerja baru, dan model bisnis. Fokus rencana program kerja Jokowi-JK untuk 2019 juga mencakup peningkatan di sektor pariwisata. Peningkatan pariwisata dan wisatawan juga meningkatkan jumlah permintaan pada industri perhotelan. Penginapan seperti hotel menjadi sesuatu yang wajib dicari apabila seseorang berkunjung ke luar kota atau luar negeri. Setiap traveler tentu memiliki budget akomodasi yang berbeda-beda. Maka dari itu, hotel juga diurutkan berdasarkan kelas yang mempengaruhi harga, fasilitas dan kualitas dari sebuah hotel. Untuk mengatasi 
maraknya persaingan antar hotel, setiap hotel melakukan pemasaran melalui media dengan tujuan untuk memperkenalkan dan memberikan branding kepada khalayak.

Kini Capsule merupakan sebuah hotel kapsul yang berada di area Pluit, Jakarta. Hotel ini menawarkan konsep hotel minimalis dalam bentuk kapsul yang memiliki sentuhan budaya Indonesia. Kini Capsule juga menawarkan jenis kamar dengan harga Rp200.000 - Rp300.000 per kamar. Dalam pemasarannya, Kini Capsule menggunakan media televisi dan media sosial. Media yang melakukan review atas Kini Capsule memberikan informasi kepada khalayak mengenai desain interior Kini Capsule serta aktivitas harian yang dibuat oleh Kini Capsule yang masih berkaitan dengan budaya Indonesia (Mempelajari cara membatik, cara memasak masakan khas Indonesia, lomba 17 Agustus).

Berdasarkan uraian diatas, peneliti tertarik untuk mengukur seberapa besar pengaruh terpaan media dalam membentuk brand image Kini Capsule pada benak konsumen Kini Capsule dengan judul: "Pemanfaatan Media Online Dalam Bisnis Perhotelan (Pengaruh Terpaan Media Pada Brand Image Kini Capsule)".

Adapun rumusan masalah yang dibuat oleh penulis sebagai berikut "Apakah terpaan media online berpengaruh terhadap brand image Kini Capsule?" dengan hipotesis Ho yaitu tidak adanya pengaruh terpaan media online terhadap brand image Kini Capsule, dan H1 yaitu adanya pengaruh terpaan media online terhadap brand image Kini Capsule. Tujuan penelitian ini adalah mengetahui pengaruh terpaan media online terhadap brand image Kini Capsule.

Penelitian terdahulu yang digunakan dalam penelitian ini bersumber dari penelitian "Studi Terpaan Media Pemasaran melalui Posting Instagram terhadap Ekuitas Merek Pelanggan Sumoboo!" dengan hasil terpaan media memberikan kontribusi sebesar $21,1 \%$ terhadap ekuitas merek, sedangkan sisanya dipengaruhi oleh variabel lain dari konsep komunikasi pemasaran yang belum diteliti.

\section{Metode Penelitian}

Penelitian yang digunakan adalah penelitian Kuantitatif, yaitu penelitian yang digunakan untuk meneliti populasi tertentu, dengan teknik pengambilan sampel umumnya dilakukan secara random, hasil analisa data bersifat statistik dan digunakan untuk menguji hipotesis yang telah diterapkan (Sugiyono, 2013:36). Peneliti menggunakan jenis penelitian ini untuk mengetahui pengaruh terpaan media online terhadap brand image Kini Capsule.

Metode penelitian yang digunakan dalam bentuk survei yang merupakan penelitian yang mengambil sampel dari seluruh populasi dengan menggunakan kuesioner sebagai instrumen pengumpul data yang sah. Metode survei umumnya digunakan untuk melihat hubungan antar variabel.

Kuesioner adalah daftar pernyataan yang dibuat berdasarkan teori yang digunakan dalam penelitian. Dalam penelitian ini, kuesioner bersifat tertutup sehingga responden telah diberikan alternatif jawaban oleh peneliti. Kuesioner diberikan melalui google form yang ditempatkan pada meja resepsionis Kini Capsule.

Peneliti melakukan survei terhadap pengunjung Kini Capsule dengan jumlah populasi yang tidak diketahui. Hal ini disebabkan oleh ketidakpastian jumlah pengunjung yang menginap di Kini Capsule. Maka dari itu, digunakan rumus Lemeshow untuk menentukan jumlah sampel. Sampel yang dihitung berdasarkan rumus Lemeshow memperoleh hasil sebagai berikut: 


$$
n=96,04=100 \text { orang }
$$

Peneliti menggunakan program SPSS versi 21 tahun 2012 untuk mengolah data dengan melakukan berbagai uji yaitu:

1. Analisis Koefisien Korelasi

Analisis ini digunakan untuk melihat apakah suatu variabel tertentu tergantung dengan variabel lainnya.

2. Uji Regresi Linear Sederhana

Analisis regresi linier sederhana digunakan untuk mengetahui pengaruh antara satu variabel independen dengan satu variabel dependen yang ditampilkan melalui bentuk persamaan regresi. (Priyatno, 2011)

3. Uji Mean Per Dimensi

Uji mean merupakan bagian dari statistik deskriptif, yaitu uji yang mencakup Mean, Modus, dan Median.

\section{Hasil Temuan dan Diskusi}

Tabel 1. Koefisien Korelasi

\begin{tabular}{llrr}
\multicolumn{4}{c}{ Correlations } \\
\hline \multicolumn{3}{c}{ Terpaan } \\
Merpaan & Pearson Correlation & $\begin{array}{c}\text { Brand_I } \\
\text { mage }\end{array}$ \\
Media & Sig. (2-tailed) & 1 & $.282^{* *}$ \\
& $\mathrm{~N}$ & 100 & .004 \\
Brand & Pearson Correlation & $.282^{* *}$ & 100 \\
Image & Sig. (2-tailed) & .004 & 1 \\
& $\mathrm{~N}$ & 100 & 100 \\
**. Correlation is significant at the 0.01 level (2-tailed).
\end{tabular}

Sumber: Hasil Pengolahan Data di SPSS versi 21

Berdasarkan hasil perhitungan diatas, nilai koefisien korelasi diperoleh nilai korelasi 0,282 dengan Sig 0,004. Menurut tabel korelasi, dapat disimpulkan bahwa terdapat hubungan antara terpaan media terhadap brand image pengunjung di Kini Capsule tetapi hubungannya lemah karena berada pada kisaran nilai 0,20-0,399.

Analisis regresi dilakukan jika korelasi antara dua variabel mempunyai hubungan sebab akibat. Berikut adalah hasil dari perhitungan regresi antar dua variabel:

Tabel 2. Analisis Regresi

\begin{tabular}{|c|c|c|c|c|c|c|}
\hline \multicolumn{7}{|c|}{ Coefficients $^{\mathrm{a}}$} \\
\hline \multirow[t]{2}{*}{ Model } & & Unstandardiz & oefficients & Standardized & $\mathrm{t}$ & Sig. \\
\hline & & $\mathrm{B}$ & Std. Error & Beta & & \\
\hline \multirow[t]{3}{*}{1} & (Constant) & 2.582 & .368 & & 7.018 & .000 \\
\hline & Terpaan & .291 & .100 & .282 & 2.908 & .004 \\
\hline & Media & & & & & \\
\hline \multicolumn{7}{|c|}{ a. Dependent Variable: Brand_Image } \\
\hline
\end{tabular}

Dari tabel diatas, didapatkan persamaan regresi sederhana, yaitu:

$\mathrm{Y}=\mathrm{a}+\mathrm{b} . \mathrm{X}$

$Y=2.582+0,291 X$ 
Berdasarkan hitungan diatas, Y (Brand image) merupakan variabel dependent dan X (Terpaan media) merupakan variabel independent. Konstan 2.582 menyatakan bahwa ketika Terpaan media atau sama dengan 0, maka nilai brand image adalah 0,291. Variabel Y menyatakan apabila terjadi setiap perubahan dari satuan nilai dari $\mathrm{X}$ akan memberikan perubahan sebesar 0,291 pada Y.

Tabel 3. Uji Mean Per Dimensi Report

\begin{tabular}{lrrrrrr}
\hline & $\begin{array}{c}\text { Dimensi } \\
\text { Frekuensi }\end{array}$ & \multicolumn{1}{c}{$\begin{array}{c}\text { Dimensi } \\
\text { Durasi }\end{array}$} & $\begin{array}{c}\text { Dimensi } \\
\text { Atensi }\end{array}$ & $\begin{array}{c}\text { Dimensi } \\
\text { Strength }\end{array}$ & $\begin{array}{c}\text { Dimensi } \\
\text { Favorability }\end{array}$ & $\begin{array}{c}\text { Dimensi } \\
\text { Uniqueness }\end{array}$ \\
\hline Mean & 3.69 & 3.64 & 3.67 & 3.64 & 3.61 & 3.69 \\
$\mathrm{~N}$ & 100 & 100 & 100 & 100 & 100 & 100 \\
Std. & .462 & .449 & .465 & .431 & .499 & .434 \\
Deviation & & & & & &
\end{tabular}

Sumber: Hasil Pengolahan Data di SPSS versi 21

Dimensi yang paling berpengaruh di dalam penelitian ini adalah dimensi pertama yakni frekuensi dalam terpaan media dan dimensi keenam yakni uniqueness dalam brand image.

Tabel 4. Koefisien Determinasi

\begin{tabular}{lrrrr}
\hline $\begin{array}{l}\text { Mode } \\
1\end{array}$ & $\mathrm{R}$ & R Square & $\begin{array}{c}\text { Adjusted R } \\
\text { Square }\end{array}$ & $\begin{array}{l}\text { Std. Error of } \\
\text { the Estimate }\end{array}$ \\
\hline 1 & $.282^{\mathrm{a}}$ & .079 & .070 & .325
\end{tabular}

a. Predictors: (Constant), Terpaan_Media

Sumber: Hasil Pengolahan Data di SPSS versi 21

$$
\begin{aligned}
& \mathrm{KD}=r^{2} \times 100 \% \\
& \mathrm{KD}=(0,282)^{2} \times 100 \%=7,9 \%
\end{aligned}
$$

Dengan hasil perhitungan diatas, disimpulkan bahwa pengaruh variabel $\mathrm{X}$ terhadap variabel $\mathrm{Y}$ adalah sebesar 7,9\% dan $92,1 \%$ sisanya merupakan faktor lain di luar penelitian yang dilakukan oleh penulis.

Analisis: Berdasarkan hasil penelitian yang sudah dilakukan, peneliti dapat menarik kesimpulan bahwa ditemukan adanya hubungan antara Terpaan media terhadap Brand Image di Kini Capsule. Melalui uji koefisien korelasi diketahui bahwa hubungan terpaan media terhadap Brand Image di Kini Capsule memiliki hubungan yang lemah, hal ini dikarenakan nilai koefisien korelasi hanya sebesar 0,282 dan tidak ada tanda negatif (-) dalam perhitungan menggunakan program SPSS 21 dapat dinyatakan bahwa hubungan yang terjadi adalah hubungan yang positif.

Melalui uji validitas, variabel X (Terpaan media) memiliki nilai $\mathrm{R}$ hitung > Corrected Item-Total Correlation (0,2) dalam pengujian kedua sehingga dapat disimpulkan bahwa setiap butir pernyataan yang diberikan sudah memenuhi syarat validitas. Sama halnya dengan variabel Y (Brand image) dengan nilai R hitungnya > Corrected Item-Total Correlation sehingga dapat dinyatakan bahwa setiap butir pernyataan dari variabel Y sudah memenuhi syarat validitas.

Melalui uji reliabilitas, variabel X (Terpaan media) dan variabel Y (Brand image) memiliki nilai Cronbach's Alpha diatas 0,4 dan diatas 0,6 untuk variabel Y yaitu 0,573 untuk variabel $\mathrm{X}$ dan 0.603 untuk variabel $\mathrm{Y}$ sehingga dapat dikatakan cukup reliabel pada variabel $\mathrm{X}$ dan reliabel untuk variabel $\mathrm{Y}$. 
Dalam uji normalitas, variabel $\mathrm{X}$ memiliki hasil normalitas sebesar 0,344 dan variabel Y memiliki hasil normalitas sebesar 0,323 dan keduanya memiliki nilai yang lebih besar dari 0,397 sehingga dapat disimpulkan kedua variabel tersebut normal.

Dari pengujian regresi, terpaan media memiliki nilai 0,291 yang berarti bahwa semakin tinggi terpaan media akan meningkatkan brand image pengunjung di Kini Capsule. Dimana konstan 2,582 menyatakan bahwa ketika Terpaan media atau sama dengan 0, maka nilai Brand image adalah 0,291, sehingga setiap perubahan dari satuan nilai X akan memberikan perubahan sebesar 0,291 pada Y.

Berdasarkan hasil perhitungan koefisien determinasi, pengaruh variabel $\mathrm{X}$ (Terpaan media) terhadap variabel Y (Brand image) adalah sebesar 7,9\% dan 92,1\% nya dipengaruhi oleh faktor lain yang tidak diteliti oleh peneliti.

\section{Simpulan}

Adanya hubungan positif tetapi lemah antara Terpaan Media dengan Brand Image Kini Capsule yang dapat dilihat melalui hasil perhitungan koefisien korelasi yaitu sebesar 0,282.

Melalui hasil uji regresi linear sederhana, $\mathrm{Y}=2.582+0,291 \mathrm{X}$ yang artinya Jika nilai X (Terpaan Media) mengalami peningkatan nilai sebesar 1 satuan, maka nilai Y (Brand Image) akan mengalami perubahan peningkatan nilai sebesar 0,291.

Berdasarkan hasil perhitungan koefisien determinasi, pengaruh variabel $\mathrm{X}$ (Terpaan media) terhadap variabel Y (Brand image) adalah sebesar 7,9\% dan 92,1\% nya dipengaruhi oleh faktor lain yang tidak diteliti oleh peneliti. Dengan demikian, dapat disimpulkan bahwa faktor pembentuk brand image terdiri dari banyak faktor, sehingga dalam penelitian ini, yaitu menggunakan unsur terpaan media hanya berpengaruh $7,9 \%$

\section{Ucapan Terima Kasih}

Penulis mengucapkan terima kasih kepada seluruh narasumber, yaitu konsumen Kini Capsule yang bersedia mengisi kuisioner penelitian ini. Kemudian ucapan terima kasih juga diberikan kepada dosen pembimbing serta teman-teman di Fakultas Ilmu Komunikasi.

\section{Daftar Pustaka}

Akdon \& Riduwan. (2010). Rumus dan Data dalam Analisis Statistika Cet 2, Alfabeta.

Annenberg Media Exposure Research Group. (2008). Linking Measures of Media Exposure to Sexual Cognitions and Behaviors: A Review, Communication Methods and Measures.

Ardianto, Komala, Karlinah. (2012). Komunikasi Massa: Suatu Pengantar. Bandung. Simbiosa Rekatama Media

Effendy, Onong Uchjana. (2008). Ilmu Komunikasi Teori dan Praktek. Bandung: PT Remaja Rosdakarya.

Ghozali, Imam. (2013). Aplikasi Analisis Multivariate dengan Program SPSS, Edisi Ketujuh. Semarang: Badan Penerbit Universitas Diponegoro. 
Dionisius Kevin, Wulan Purnama Sari: Pengaruh Terpaan Media Online Terhadap Brand Image Kini Capsule

Kini Capsule. (2018). Kini Capsule Instagram Profile. <https://www.instagram.com/kinicapsule>. Diunduh tanggal 5 September 2018.

Knobloch-Westerwick, Silvia. (2014). Choice and Preference in Media Use: Advances in Selective Exposure Theory and Research. London: Routledge.

Kompas Travel. (2016). Gebrakan Presiden Jokowi Gairahkan Sektor Pariwisata. Lhttps://travel.kompas.com/read/2016/05/28/201600127/Gebrakan.Presiden.Jo kowi.Gairahkan.Sektor.Pariwisata $>$. Diunduh tanggal 5 September 2018.

Kotler, Philip dan Kevin Lane Keller. (2009). Manajemen Pemasaran Jilid 1 (Edisi 13). Jakarta: Erlangga

Kriyantono, Rachmat. (2010). Teknik Praktis Riset Komunikasi: Disertai Contoh Praktis Riset Media, Public Relation, Advertising, Komunikasi Organisasi, Komunikasi Pemasaran. Jakarta: Kencana.

Marta, R., \& Monica William, D. (2017). Studi Terpaan Media Pemasaran Melalui Posting Instagram Terhadap Ekuitas Merek Pelanggan Sumoboo!. Jurnal Komunikasi, 8(1), 68-82. Retrieved from $<$ https://journal.untar.ac.id/index.php/komunikasi/article/view/50/53 > . Diunduh tanggal 5 September 2018.

Maxmanroe. (2017). Strategi Pemasaran Modern. <https://www.maxmanroe.com/strategi-pemasaran-modern.html >. Diunduh tanggal 12 Oktober 2018.

Rangkuti, Freddy. (2009). Strategi Promosi yang Kreatif dan Analisis. Kasus. Integrated Marketing Communication. Jakarta: PT. Gramedia Pustaka Utama.

Suara. (2016). Asosiasi Hotel Akui Ada Peningkatan Tamu Berkat Promosi Wisata. <https://www.suara.com/bisnis/2016/01/26/152933/asosiasi-hotel-akui-adapeningkatan-tamu-berkat-promosi-wisata $>$. Diunduh tanggal 5 September 2018.

Sugiyono. (2013). Metode Penelitian Pendidikan Pendekatan Kuantitatif, Kualitatif, dan $R \& D$. Bandung: Alfabeta.

Sujarweni, V. Wiratna. (2014). Metode Penelitian: Lengkap, Praktis, dan Mudah Dipahami. Yogyakarta: Pustaka Baru Press.

Tribun News. (2018). Bisnis Perhotelan di Indonesia Memasuki Era Baru. $\leq$ http://www.tribunnews.com/bisnis/2018/01/19/bisnis-perhotelan-diindonesia-memasuki-era-baru $>$. Diunduh tanggal 15 September 2018. 